\title{
Demand pattern and willingness to pay for high value fish consumption: Case study from selected coastal cities in Kerala, south India
}

\author{
SHYAM S. SALIM \\ ICAR-Central Marine Fisheries Research Institute, Kochi - 682 018, Kerala, India \\ e-mail: shyam.icar@gmail.com
}

\begin{abstract}
Fishing occupies an important place in the economy of Kerala State, south India as a vital source of food and protein, avenue for employment and most importantly in the export market. Kerala's population is basically a fish eating population where the level of fish consumption is four times the national average. The annual per capita fish consumption has increased from $15 \mathrm{~kg}$ in $1970 \mathrm{~s}$ to about $23 \mathrm{~kg}$ in 2011. The high value fishes like shrimps, squids, seerfishes and pomfrets are massively exported due to economies of scale, thereby leading to limited local availability resulting in high domestic prices. The present study assessed the fish intake pattern across 600 middle income consumer households of urban area in the metropolitan cities of Thiruvananthapuram, Kochi and Kozhikode in Kerala. The average family size was found to be 4.2. The study concentrated on income cum expenditure pattern, buying trend, hindrances in fish consumption and readiness to pay for high value fishes. Willingness to pay was figured out using logit model. The results indicated that the income and access to the selling points of fish enhanced the demand. The per capita monthly fsh consumption was found to be $2.2 \mathrm{~kg}$ with low value per capita fish consumption estimated at $1.43 \mathrm{~kg}$ and average high value per capita fish consumption at $0.77 \mathrm{~kg}$ across study areas. The fish food consumption pattern trends across the different study locales clearly portrayed that there exists significant demand for high value fish and fish products. Most local consumers weren't aware about low export price and more than $50 \%$ expressed their willingness to pay which indicated existence of a high consumer surplus. Resutls of the study stressed the need for governmental intervention in controlling fish exports thereby safeguarding local fish food security, replacing exports with local marketing; considering the demand for sizeable quantum and ample readiness to pay.
\end{abstract}

Keywords: Consumption pattern, Constraint analysis, Garrette ranking, High value fishes, Low value fishes, Logit model, Willingness to pay

\section{Introduction}

Fishing plays an important role in the economy of the state of Kerala, south India, as it is a vital source of food and protein, provides a major employment opportunity and in recent years it has contributed significantly to the export market. Kerala is the largest fish consuming state in the country with more than $85 \%$ of the population eating fish at an average per capita fish consumption of $27-30 \mathrm{~kg}$ which is four times the national average (Shyam et al., 2013; 2017). Among the major states, Kerala has the highest monthly per capita fish consumption $(1.91 \mathrm{~kg})$, followed by West Bengal (0.77 kg) and Assam (0.63 kg) (Yadava, 2007). Per capita fish consumption stood at $15 \mathrm{~kg}$ per annum during the early 70 s which declined subsequently, but the fact remains that even in the humblest of the households there is at least one meal with fish everyday (Gulati, 1984). Fish production in Kerala during 2018-19 recorded 8.01 lakh t out of which, 6.09 lakh $t$ was contributed by marine fisheries and the rest by inland fisheries (Gok, 2019). The fisheries sector in Kerala provides employment to about 2.14 lakh people comprising 1.45 lakh in the primary and
0.65 lakh in the secondary and tertiary sectors. The sector also supports the livelihood for about 10 lakh people (Gogoi et al., 2015).

The local market for fish in Kerala is influenced by the consumers' purchasing power along with their tastes and preferences. The percentage of non-vegetarians in India's population ranges from $80-85$. The fish prices across Kerala are on the rise as the local market is growing at a rate of $25-30 \%$. Intake of fish in Kerala is growing substantially with change in lifestyle and rising cost of meat. Kerala will be a net deficit state in terms of fish availability and needs to rely on arrivals or imports for domestic supply. For daily consumption, on an average of 2000-2500 t of fish is required and the domestic supply caters to only $60 \%$. The remaining has to be sourced or imported from other states or countries. The demandsupply gap will be widened every year, indicating that Kerala will require $50 \%$ of fish from other states to meet the demand in 2035 (The Business Line, 2017). The retail market turning unstable with the price spiral is a common experience. Seerfish costs between ₹530-640 per $\mathrm{kg}$ on 
an average, while pearlspot costs between ₹340-420 a kg. Medium sized shrimps come at over ₹325 per kg and the oilsardines between ₹100-175 per kg (CMFRI, 2019).

The increasing export demand has resulted in the movement of fish from domestic markets to export markets, especially for groups like cephalopods, squids and perches which led to sudden increase in price of these commodities (DFID, 2003). As a consequence, trawling and artisanal operations started targeting these groups. A higher consumer price in the importing countries for quality products will reduce the burden of the exporters in Kerala to implement quality standards for marine products. Consumers in the importing countries may have to pay more for safer seafood from developing countries (Rajasenan, 2012).

An attempt was made to analyse fish consumption pattern of urban consumers across selected coastal cities in Kerala viz., Thiruvananthapuram, Kochi and Kozhikode having sizeable middle/high income population with higher purchasing power. The primary data on the pattern of expenditure, fish consumption, buying behaviour, constraints in high value fish consumption and willingness to pay for high value fishes were collected. The study outline was to assess the fish consumption profile in the identified cities to ascertain the elements related to fish consumption and to delineate the limits to high value fish consumption.

\section{Materials and methods}

Primary data on age, education, income and expenditure pattern, fish consumption, buying behaviour, limits to high value fish consumption and willingness to pay were collected from a total of 600 households in Thiruvananthapuram (240), Kochi (240) and Kozhikode (120) during the period from January - December 2012.

Willingness to pay (WTP) is the highest amount of money an individual agrees to pay for a service or product. The WTP function illustrates the range of price an individual is willing to pay for a given level of quality at given specific levels of price (p) and utility (U) (Lusk and Hudson, 2004). Contingent valuation method uses survey response to deduce consumers' WTP and is considered as a hypothetical valuation method (Maynard and Franklin, 2003). The Logit model was employed and it takes up the random variable $Z_{\mathrm{i}}$ which predicts the log of the odds ratio of consumers' willingness to pay more (LWTP) (Greene and Hensher, 2013):

$$
\begin{aligned}
& \mathrm{LWTP}=\mathrm{Z}_{\mathrm{i}}=\ln \left(\mathrm{Pi} / 1-\mathrm{P}_{\mathrm{i}}\right)=\beta_{0}+\beta_{1} \mathrm{~A}+\beta_{2} \mathrm{E}+\beta_{3} \mathrm{~F}+\beta_{4} \mathrm{Y}+ \\
& \beta_{5} \mathrm{D}+\beta_{6} \mathrm{P}_{\mathrm{f}}+\beta_{7} \mathrm{P}_{\mathrm{s}}+\beta_{8} \mathrm{R}
\end{aligned}
$$

where, $\mathrm{LWTP}=\log$ odds ratio of the willingness to pay; $\mathrm{Z}_{\mathrm{i}}=\log$ of Odds ratio; $\mathrm{P}_{\mathrm{i}} / 1-\mathrm{P}_{\mathrm{i}}=$ Odds ratio; $\mathrm{A}=$ Age in years of the head of household; $\mathrm{E}=$ Education level of the head of household; F = Family size in numbers; $\mathrm{Y}=$ Monthly income in rupees; $\mathrm{D}=$ Proximity to buying source $(\mathrm{km}) ; \mathrm{P}_{\mathrm{f}}=$ Price of fish in Rupees; $\mathrm{P}_{\mathrm{s}}=$ Price of substitutes (Meat - Weighted average) in Rupees; $\mathrm{R}=$ Ranks weighing from 1-5.

The likelihood of consumers' willingness to pay for high value fishes is empirically assessed as a function of various individual consumers and household level factor. The model can be represented as: $\mathrm{P}_{\mathrm{i}}=\mathrm{e}^{\mathrm{Zi}} /\left(1+\mathrm{e}^{\mathrm{Zi}}\right)$

where, $\mathrm{P}_{\mathrm{i}}=$ Likelihood of the $\mathrm{i}^{\text {th }}$ consumers' willingness to pay more

The dependent variable is the individual's decision on willingness to pay (WTP) for high value fishes which records 1 , if the individual is willing to pay more for high value fishes and 0 if not. Logit model expresses the individual's decision on the agreement to pay for offered supply available or for augmented supply available. The marginal effects of the variable are computed based on the logit coefficient of that variable while all other variables are held constant. The computations were done using LOGISTIC Procedure of SAS ( PROC LOGISTIC).

$$
\text { Marginal effect for } \mathrm{X}_{\mathrm{k}}=\mathrm{P}(\mathrm{Y}=1 \mid \mathrm{X}) * \mathrm{P}(\mathrm{Y}=0 \mid \mathrm{X}) * \mathrm{bk}
$$

Garette Ranking Technique ranked the limitations expressed by the consumers in relation to fish consumption based on the pilot study and their order of consumers worth was transmitted into scores. Percent position was worked out by converting the scores assigned by the consumers towards the particular limitation using the formula (Garrett, 1969):

Table 1. Age-wise distribution of head of households

\begin{tabular}{lllll}
\hline \multirow{2}{*}{ Age } & \multicolumn{4}{c}{ Number of respondents } \\
\cline { 2 - 5 } & Thiruvananthapuram & Kochi & Kozhikode & Total \\
\hline$<35$ & $58(24.17)$ & $49(20.42)$ & $31(25.83)$ & $138(23.00)$ \\
$36-60$ & $147(61.25)$ & $153(63.75)$ & $60(50.00)$ & $360(60.00)$ \\
$>60$ & $35(14.58)$ & $38(15.83)$ & $29(24.17)$ & $102(17.00)$ \\
Total & $240(100)$ & $240(100)$ & $120(100)$ & $600(100.00)$ \\
\hline
\end{tabular}

Figures in parentheses indicate percentages to total 


$$
\text { Percent Position }=\frac{100(\mathrm{Rij}-0.05)}{\mathrm{Nj}}
$$

where, $\mathrm{R}_{\mathrm{ij}}=$ Rank given for the $\mathrm{i}^{\text {th- }}$ problem by the $\mathrm{j}^{\text {th }}$ consumer; $\mathrm{N}_{\mathrm{j}}=$ Number of attributes

\section{Results and discussion}

Socio-economic profile

Age-wise distribution of head of households

The age-wise distribution of head of households in Thiruvananthapuram, Kochi and Kozhikode cities is furnished in Table 1 . The results indicated that $60 \%$ of the respondents in the study area came under the age group of $36-60$, followed by a total of $23 \%$ coming under $<35$ age group and $17 \%$ under $>60$ age group.

\section{Educational status}

The location-wise educational status of head of households is furnished in Table 2. Among the

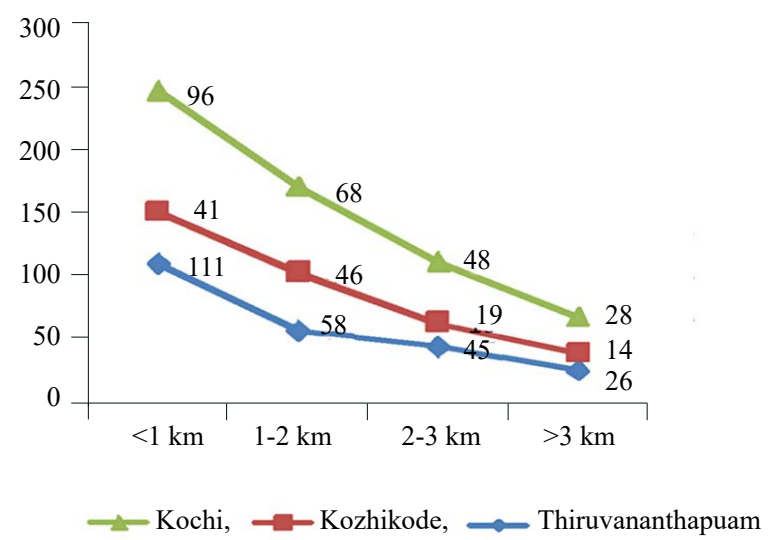

Fig. 1. Access for the consumers to fish selling points in Thiruvananthapuram, Kochi and Kozhilode cities

Table 2. Educational status of respondents

\begin{tabular}{lllll}
\hline Education & Thiruvananthapuram & Kochi & Kozhikode & Total \\
\hline Primary & $10(4.17)$ & $8(3.33)$ & $6(2.50)$ & $24(4.00)$ \\
High school & $64(6.67)$ & $59(24.58)$ & $24(10.00)$ & $147(24.50)$ \\
Secondary & $83(34.58)$ & $83(34.58)$ & $62(25.83)$ & $228(38.00)$ \\
College education & $83(34.58)$ & $90(37.50)$ & $28(33.50)$ & $201(33.50)$ \\
Total & $240(100.00)$ & $120(100.00)$ & $240(100.00)$ & $600(100.00)$ \\
\hline
\end{tabular}

Figures in parentheses indicate percentages to total

Table 3. Mean income levels of households

\begin{tabular}{llll}
\hline Income $(₹)$ & \multicolumn{2}{c}{ Number of respondents } \\
\cline { 2 - 3 }$>25000$ & Thiruvananthapuram & Kochi & Kozhikode \\
$25000-50000$ & $84(35.00)$ & $62(26.83)$ & $15(6.25)$ \\
$50000-100000$ & $66(27.50)$ & $81(30.83)$ & $38(15.83)$ \\
$>100000$ & $68(28.33)$ & $58(29.17)$ & $49(20.42)$ \\
Total & $22(9.17)$ & $39(13.17)$ & $18(7.50)$ \\
\hline
\end{tabular}

Figures in parentheses indicate percentages to total respondents, $38 \%$ possessed secondary education followed by collegiate level (33.5\%). High school level education was possessed by $24.5 \%$ of respondents while $4 \%$ had only primary education.

\section{Access to selling points}

Access to the selling points enhanced the fish demand and is depicted in Fig. 1. The analysis showed that 248 sample respondents (41.33\%) had close access to fish selling points with in a kilometre. A total of 172 respondents (28.67\%) and 112 respondents (18.67\%) had access to fish selling points with in 1-2 km and 2-3 km respectively. For $11.33 \%$ of the respondents, selling point was situated $>3 \mathrm{~km}$ away. The results indicated that consumers were able to access fish within a short distance.

\section{Income, expenditure and consumption patterns}

Income favourably affected the fish demand and the average income level of households is shown in Table 3. The mean level of household income amongst the respondents indicated that $30.83 \%$ of the respondents had an income in the range of ₹25000-50000 followed by a total of $29.17 \%$ of the respondents possessing an income between $₹ 50,000$ to 100,$000 ; 26.83 \%$ of the respondents possessing income < ₹ 25000 and $13.17 \%$ having income level $>₹ 1$ lakh. The highest mean income was registered with households in Kozhikode (₹49606.98), followed by Kochi (₹45028.95) and Thiruvananthapuram (₹41795.44).

The mean monthly expenditure pattern of respondents in selected cities is furnished in Table 4. It was found that majority of their income is spent on food items, the highest being for Kochi followed by Kozhikode and Thiruvananthapuram. A total of $23.92 \%$ (₹7150.17) is spent for food items in Kochi, whereas it was $23.81 \%$ 
Table 4. Average monthly expenditure pattern of respondents

\begin{tabular}{|c|c|c|c|}
\hline \multirow{2}{*}{ Expenditure pattern } & \multicolumn{3}{|c|}{ Amount (₹) } \\
\hline & Thiruvananthapuram & Kochi & Kozhikode \\
\hline Food & $7033.34(22.80)$ & $7150.17(23.92)$ & $7433.01(23.81)$ \\
\hline Clothing & $1795.35(5.82)$ & $1832.38(6.13)$ & $2222.72(7.12)$ \\
\hline Shelter & $3510.50(11.38)$ & $3028.06(10.13)$ & $3087.46(9.89)$ \\
\hline Fuel/Electricity & $2813.34(9.12)$ & $2678.32(8.96)$ & $2709.72(8.68)$ \\
\hline Health care & $3140.33(10.18)$ & $3084.85(10.32)$ & 3471.44 (11.12) \\
\hline Education & $3334.67(10.81)$ & $3072.90(10.28)$ & $3530.76(11.31)$ \\
\hline Social expenses & $4075.02(13.21)$ & $3536.22(11.83)$ & $4002.15(12.82)$ \\
\hline Others & $5145.45(16.68)$ & $5509.10(18.43)$ & $4760.75(15.25)$ \\
\hline Total & $30848.00(100.00)$ & $29892.00(100.00)$ & $31218.00(100.00)$ \\
\hline
\end{tabular}

Figures in parentheses indicate percentages to total

in Kozhikode (₹7433.01) and 22.8\% (₹7033.34) in Thiruvananthapuram. The monthly expenditure on clothing was the least along the three regions, viz., $7.12 \%$ in Kozhikode, $6.13 \%$ in Kochi and $5.82 \%$ in Thiruvananthapuram. The highest monthly social expenditure was registered in Kozhikode (12.82\%) and the lowest in Kochi (11.83\%). A comparatively higher amount of ₹3530.76 (11.31\%) was being spent for educational purposes in Kozhikode whereas the lowest being incurred in Thiruvananthapuram city with a total amount of ₹3334.67 (10.81\%). Thiruvananthapuram had the maximum mean expenditure $(73.80 \%)$ followed by Kochi (66.38\%) and Kozhikode (62.93\%).

\section{Mean monthly expenditure on food}

The mean monthly expenditure on various food items for the chosen cities (Thiruvananthapuram, Kozhikode and Kochi) is depicted in Table 5. The maximum mean expenditure was incurred for cereals across all other food items with the highest for Kochi (₹1279.65 i.e. 17.9\%) followed by Kozhikode (₹1327.06; $17.85 \%$ ) and Thiruvananthapuram (₹1243.15; 17.68\%). The mean monthly expenditure incurred for fish and fish products was highest in Thiruvananthapuram (17.6\%) and
Kozhikode (16.95\%) respectively, while the same for fish and fish products was lowest for Kochi (15.94\%). The mean expenditure for meat and meat products was lowest in Thiruvananthapuram (14.63\%).

Mean monthly consumption and average prices of meat and fish products

The mean monthly consumption of meat and fish products in Thiruvananthapuram, Kozhikode and Kochi is presented in Table 6 . The average monthly consumption was maximum for chicken in the study areas. Amongst the three cities, the mean monthly consumption of chicken was found to be the highest in Kozhikode $(3.31 \mathrm{~kg})$ followed by Kochi $(2.81 \mathrm{~kg})$ and Thiruvananthapuram $(2.21 \mathrm{~kg})$. It can be seen that low value fishes were consumed more than high value fishes in the study areas. The consumption of low value fishes as well as high value fishes was comparatively high in Kochi. The average low value fish consumption was $6 \mathrm{~kg}$ whereas the average high value fish consumption was found to be $3.26 \mathrm{~kg}$ across the study areas.

The mean price of meat and meat products is depicted in Fig. 2. The mean price for mutton was found to be the highest compared to other meat and meat

Table 5. Average monthly expenditure on food

\begin{tabular}{llll}
\hline \multirow{2}{*}{ Expenditure on food } & \multicolumn{3}{l}{ Amount $(₹)$} \\
\cline { 2 - 3 } & Thiruvananthapuram & Kochi & Kozhikode \\
\hline Cereals & $1243.15(17.68)$ & $1279.65(17.90)$ & $1327.06(17.85)$ \\
Pulses & $666.67(9.48)$ & $696.84(9.75)$ & $862.13(11.60)$ \\
Oil & $300.79(4.28)$ & $230.75(.23)$ & $294.14(3.96)$ \\
Fruits and vegetables & $755.30(10.74)$ & $760.12(10.63)$ & $679.6(9.14)$ \\
Milk and dairy products & $780.40(11.10)$ & $834.82(11.68)$ & $736.39(9.91)$ \\
Beverages (Tea and coffee) & $484.7(6.89)$ & $414.86(5.80)$ & $530.36(7.14)$ \\
Meat and meat products & $1029.03(14.63)$ & $1175.13(16.44)$ & $1262.50(16.99)$ \\
Fish and fish products & $1238.00(17.60)$ & $1139.39(15.94)$ & $1259.70(16.95)$ \\
Others & $535.29(7.61)$ & $618.6(8.65)$ & $481.12(6.47)$ \\
Total & $7033.34(100.00)$ & $7150.17(100.00)$ & $7433.01(100.00)$ \\
\hline
\end{tabular}

Figures in parentheses indicate percentages to total 
products in Thiruvananthapuram, Kozhikode and Kochi cities. Mean price realised for mutton was highest in Thiruvananthapuram (₹420) followed by Kochi (₹360) and Kozhikode (₹330). Whereas the mean price for chicken was highest in Kochi (₹155) followed by Kozhikode (₹148) and Thiruvananthapuram (₹140). Excluding other meat products, the mean price was found to be the lowest for chicken (₹140) in Thiruvananthapuram and the same was found to be the lowest for pork (₹120) in Kozhikode and for beef (₹152) in Kochi.

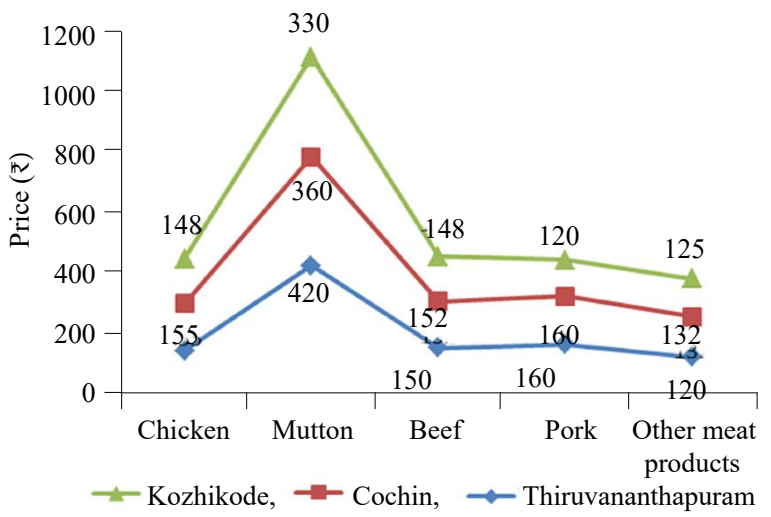

Fig. 2. Mean price of meat and meat products (₹) in Thiruvananthapuram, Kochi and Kozhikode cities
Mean monthly consumption and average prices of low value and high value fishes

The mean monthly fish consumption in Thiruvananthapuram, Kozhikode and Kochi is shown in Table 7. The monthly mean fish consumption of low value fishes registered highest in Thiruvananthapuram $(6.25 \mathrm{~kg})$ followed by Kochi $(6.33 \mathrm{~kg})$ and Kozhikode $(5.42 \mathrm{~kg})$. The monthly mean fish consumption of high value fishes was highest in Kozhikode $(3.52 \mathrm{~kg})$; followed by Thiruvananthapuram $(3.26 \mathrm{~kg})$ and Kochi $(3.01 \mathrm{~kg})$. Thus Thiruvananthapuram reported highest mean monthly consumption $(9.51 \mathrm{~kg})$ followed by Kochi $(9.34 \mathrm{~kg})$ and Kozhikode $(8.94 \mathrm{~kg})$.

Among the low value fishes, consumption of mackerel was found to be the highest in all the three cities with $1.7 \mathrm{~kg}$ (the highest) in Kozhikode, $1.42 \mathrm{~kg}$ and $1.3 \mathrm{~kg}$ (lowest) in Thiruvananthapuram and Kochi respectively. Among the high value fishes, consumption of shrimps was found to be the highest in all the three cities with $1.1 \mathrm{~kg}$ (the highest) in Kozhikode, $0.85 \mathrm{~kg}$ and $0.65 \mathrm{~kg}$ (lowest) in Thiruvananthapuram and Kochi respectively. The pattern of monthly mean consumption of low value fishes and that of high value fishes exhibited similar levels, with maximum consumption in Kozhikode and the lowest in Kochi.

Table 6. Mean monthly consumption of meat and fish products $(\mathrm{kg})$

\begin{tabular}{lllll}
\hline Monthly consumption $(\mathrm{kg})$ & Thiruvananthapuram & Kochi & Kozhikode & Total \\
\hline Chicken & 2.21 & 2.81 & 3.31 & 2.78 \\
Mutton & 1.12 & 1.02 & 1.58 & 1.24 \\
Beef & 1.15 & 1.56 & 1.32 & 1.34 \\
Pork & 0.12 & 0.50 & 0.11 & 0.24 \\
Other meat products & 0.48 & 0.42 & 0.341 & 0.41 \\
Low value fishes & 6.25 & 6.33 & 5.42 & 6.00 \\
High value fishes & 3.26 & 3.01 & 3.52 & 3.26 \\
Total fish consumption & 9.51 & 9.34 & 8.94 & 9.27 \\
\hline
\end{tabular}

Table 7. Mean monthly consumption of fishes (kg per household)

\begin{tabular}{lllll}
\hline Species & Thiruvananthapuram & Kochi & Kozhikode & Total \\
\hline Sardines & 2.12 & 2.41 & 1.42 & 1.98 \\
Mackerels & 1.42 & 1.3 & 1.7 & 1.47 \\
Anchovies & 1.29 & 1.2 & 0.81 & 1.10 \\
Other Low value fishes & 1.42 & 1.42 & 1.49 & 1.44 \\
Total Low value fishes & 6.25 & 6.33 & 5.42 & 6.00 \\
Shrimps & 0.85 & 0.65 & 1.1 & 0.87 \\
Cephalopods & 0.35 & 0.37 & 0.44 & 0.39 \\
Seerfishes & 0.54 & 0.58 & 0.7 & 0.61 \\
Pomfrets & 0.64 & 0.64 & 0.68 & 0.65 \\
Ribbonfishes & 0.55 & 0.44 & 0.22 & 0.40 \\
Other high value fishes & 0.33 & 0.33 & 0.38 & 0.35 \\
Total high value fishes & 3.26 & 3.01 & 3.52 & 3.26 \\
Mean monthly consumption & 9.51 & 9.34 & 8.94 & 9.26 \\
Per capita mean monthly consumption & 2.26 & 2.22 & 2.12 & 2.20 \\
\hline
\end{tabular}




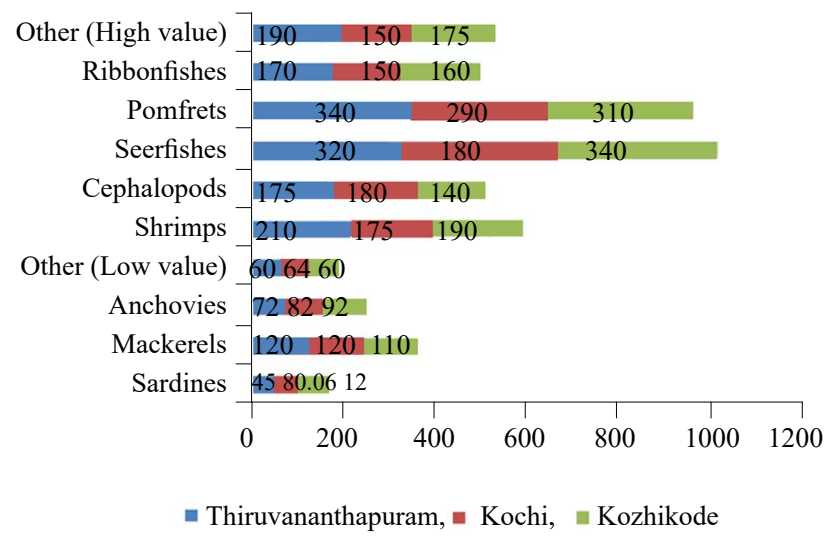

Fig. 3. Mean price (₹) of fish in the selected cities

The average price of fishes realised in Thiruvananthapuram, Kozhikode and Kochi is shown in Fig. 3. The highest mean price was calculated for pomfrets (₹340) in Thiruvananthapuram and the same for seerfishes in Kozhikode (₹340) and Kochi (₹330). Similarly, the lowest mean price was found for Sardines in all the three cities i.e., ₹48, ₹60 and ₹50 in Thiruvananthapuram, Kozhikode and Kochi respectively. The study results indicated that price differentials amongst cities were not high, with variation less than $10 \%$.

\section{Limits to fish consumption}

The limits to domestic fish consumption perceived by the consumers was analysed by constraint analysis (Table 8). The major constraint observed in Kochi was high price (56.9) followed by extensive fluctuations in price (55.89), access to the source of purchase (54.38), consumption restricted to social functions (53.48), lack of quality fresh fish (52.18) and non-availability of preferred species (28.35). Lack of quality fresh fish (56.9) was the main constraint observed in Thiruvananthapuram succeeded by problems like consumption restricted to social functions (55.89), high price (54.38), access to the source of purchase (53.48), non-availability of preferred species (52.18) and extensive fluctuations in price (28.35). Access to the source of purchase was found to be the major constraint followed by lack of fresh fish (55.89), high price (54.38), wide fluctuations in price (53.48), nonavailability of preferred species (52.18) and consumption restricted to seasonality in consumption (social functions) (28.35) in Kozhikode.

\section{Status of high value fish consumption}

The status of awareness on high value fish consumption is shown in Table 9. A total of $71.75 \%$ of consumers from Kochi were unaware of the low export prices of high value fishes, followed by 80.45 and $71.71 \%$

Table 8. Problems in domestic consumption - Garrette ranking

\begin{tabular}{|c|c|c|c|c|c|c|c|}
\hline \multirow{2}{*}{ Sl. No. } & \multirow{2}{*}{ Reasons } & \multicolumn{2}{|c|}{ Thiruvananthapuram } & \multicolumn{2}{|c|}{ Kochi } & \multicolumn{2}{|c|}{ Kozhikode } \\
\hline & & Score & Rank & Score & Rank & Score & Rank \\
\hline 1. & Non-availability of preferred species & 52.18 & $\mathrm{~V}$ & 28.35 & VI & 52.18 & $\mathrm{~V}$ \\
\hline 2. & Lack of quality fresh fish & 56.90 & I & 52.18 & $\mathrm{~V}$ & 55.89 & II \\
\hline 3. & Extensive fluctuations in price & 28.35 & VI & 55.89 & II & 53.48 & IV \\
\hline 4. & High price & 54.38 & III & 56.9 & I & 54.38 & III \\
\hline 5. & Access to the source of purchase & 53.48 & IV & 54.38 & III & 56.9 & I \\
\hline 6. & Seasonality in consumption (social functions) & 55.89 & II & 53.48 & IV & 28.35 & II \\
\hline
\end{tabular}

Table 9. Awareness on the consumption of high value fishes ( $\%$ of respondents)

\begin{tabular}{|c|c|c|c|c|}
\hline Sl. No. & Parameter & Thiruvananthapuram & Kochi & Kozhikode \\
\hline 1. & Awareness on low export prices of high value fishes & 19.55 & 28.25 & 18.29 \\
\hline 2. & Preference to eat if available & & & \\
\hline $\mathrm{i}$ & Never & 10.42 & 16.21 & 9.62 \\
\hline ii & Very rarely & 29.42 & 22.55 & 21.89 \\
\hline iii & Rarely & 26.48 & 28.19 & 26.42 \\
\hline iv & Frequently & 23.21 & 22.47 & 30.18 \\
\hline $\mathrm{v}$ & Very frequently & 10.47 & 10.58 & 11.89 \\
\hline 3. & Willingness to pay more price if available & & & \\
\hline $\mathrm{i}$ & Never & 8.78 & 7.85 & 9.10 \\
\hline ii & Very rarely & 11.18 & 10.94 & 12.98 \\
\hline iii & Rarely & 31.45 & 37.95 & 33.61 \\
\hline iv & Frequently & 26.45 & 23.46 & 24.19 \\
\hline $\mathrm{v}$ & Very frequently & 22.14 & 19.8 & 20.12 \\
\hline 4. & Willingness to pay more price if available? Yes & 32.18 & 36.15 & 38.35 \\
\hline
\end{tabular}


respectively in Thiruvananthapuram and Kozhikode. In Kozhikode, $39.35 \%$ were ready to pay more prices if fishes were available, whereas only 38.35 and $36.15 \%$ in Kochi and Thiruvananthapuram were ready for the same. It was found that $38 \%$ of the consumers felt that they get high value fishes very rarely for consumption. On the other side, $36 \%$ of the respondents preferred to eat high value fishes very frequently if available. Majority of the consumers from Thiruvananthapuram (31.45\%), Kozhikode (31.25\%) and Kochi (37.95\%) opined that they hardly ever get high value fishes. Majority of the consumers in Kozhikode $(31.25 \%)$ and Thiruvananthapuram $(29.42 \%)$ preferred regular consumption of high value fishes.

Willingness to pay - Logit functions

The willingness to pay for high value fishes was determined by a WTP function:

$\mathrm{WTP}=\mathrm{f}(\mathrm{AGE}, \mathrm{EDN}$, FSIZE, INC, PROX, PFISH, PSUBS, TAS)

The willingness to pay model was estimated for the three study areas and the functional form is:

$\mathrm{WTP}=\mathrm{f}(\mathrm{AGE}, \mathrm{EDN}, \mathrm{FSIZE}, \mathrm{INC}$, PROX, PFISH, PSUBS, TAS)

$\mathrm{WTP}_{\text {fish }}=\mathrm{f}\left(\mathrm{A}, \mathrm{E}, \mathrm{F}, \mathrm{Y}, \mathrm{D}, \mathrm{P}_{\mathrm{f}} \mathrm{P}_{\mathrm{s}} \mathrm{T}\right)$

where A - Age, E - Education, F- Family size, Y - Income, $\mathrm{D}$ - Access to the buying source, $\mathrm{P}_{\mathrm{f}-}$ Fish Price, $\mathrm{P}_{\mathrm{s}}$ - Price of substitutes and $\mathrm{T}$ - taste and preferences

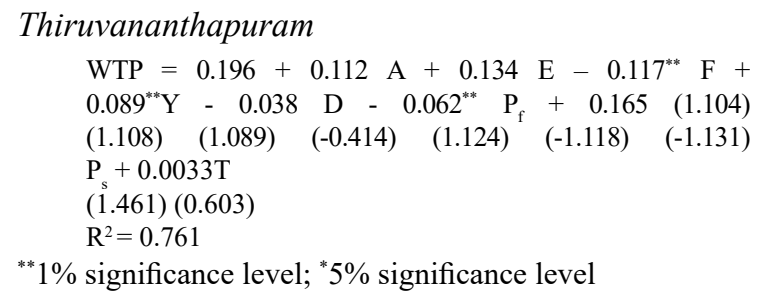

Figures in brackets indicates estimated ' $t$ ' ratios

The outcomes indicated that the willingness to pay for fish registered positive relationship with age, education, income, price of substitutes and taste and preferences. The price of fish, family size and access to the buying source adversely affected the willingness to pay. The analysis indicated that for every $10 \%$ increase in the price of fish, the willingness to pay for high value fishes decreased by $0.62 \%$ from the mean level, other things remaining constant

\section{Kochi}

$\mathrm{WTP}=0.361+0.192 \mathrm{~A}+0.132 \mathrm{E}-0.148^{* *} \mathrm{~F} 0.0125^{* *} \mathrm{Y}-0.314$

$\mathrm{D}+0.087^{* *} \mathrm{P}_{\mathrm{f}}+0.248(1.692)(1.104)(1.124)(1.491)(0.918)$

$(-1.179)(-1.098)(1.342)$

$\mathrm{P}+0.0189 \mathrm{~T}$

(0.512)

$\mathrm{R}^{2}=0.742$

** $1 \%$ significance level; ${ }^{*} 5 \%$ significance level

Figures in brackets indicates estimated ' $t$ ' ratios
The outcome indicated that the willingness to pay for fish registered positive relationship with age, education, income, price of substitutes and taste and preferences. The willingness to pay was adversely affected by family size and access to the selling source. The analysis indicated that for every $10 \%$ increase in the family size, the willingness to pay decreases by $1.48 \%$ from the mean level cetreris paribus. It was surprising to find that the consumers were willing to pay for high value fishes with increasing price of fish thus indicating a high consumer surplus. It was found that for every $10 \%$ increase in the price of fish an increase in the willingness to pay for high value fishes, by $0.87 \%$ from the mean level ceteris paribus.

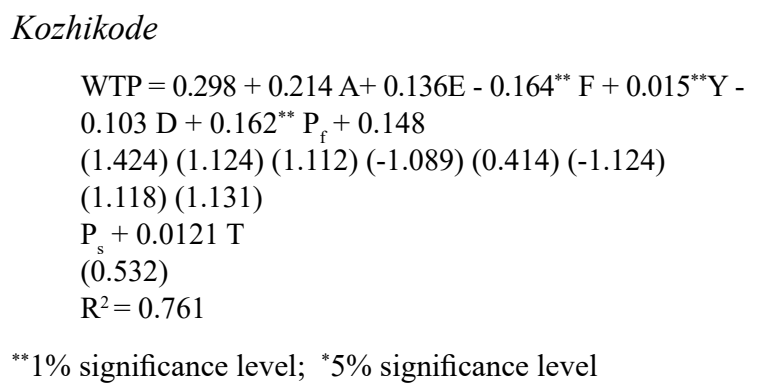

Figures in parenthesis indicates estimated ' $t$ ' ratios

The outcome indicated that the willingness to pay for fish registered positive relationship with age, education, income, price of substitutes and taste and preferences. The willingness to pay was negatively affected by family size, access to the buying source and price of fish. It was found that for every $10 \%$ increase in the family size, the willingness to pay decreases by $1.64 \%$ from the mean level cetreris paribus. The analysis also revealed that every $10 \%$ increase in the price of fish leads to an increased demand in the willingness to pay for high value fishes by $1.62 \%$ from the mean level ceteris paribus. However, with increasing price of substitutes for every $10 \%$ increase would lead to a surge in demand for fish by $1.48 \%$ from the mean level ceteris paribus.

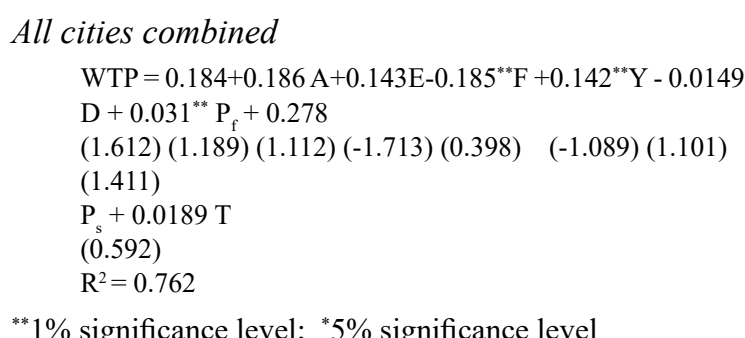

Figures in brackets indicates estimated ' $t$ ' ratio

The price comparison of high value species like cephalopods, pomfrets, seer and ribbon fishes indicated that the domestic prices were on an average 20 to $25 \%$ more than the export prices (Shyam et al., 2012). This 
is mainly because of the fact that high value fishes do not cater to the domestic market on account of low and inconsistent demand. The exporters in order to reap the export economies of scale tend to export more quantity of fish at lower price margins. The revenue gains are contributed mostly by quantity effect rather than the price effect (Shyam, 2013). The irony of trading sizeable quantum at a lesser export price together with alert threats and export rejections call for tapping the domestic markets so that the fish food is available across India. Although, the exports receive worthwhile earnings, the fish food security of the domestic consumer will be under threat. All these pose threats to availability and cost-effectiveness of high value fishes in domestic markets (Shyam, 2013).

The analysis revealed that the willingness to pay for fish registered positive relationship with age, education, income, price of substitutes and taste and preferences. Access to the buying source negatively affected the willingness to pay. It was surprising to find that the consumers willing to pay for high value fishes was more with increasing price of fish thus indicating a high consumer surplus. The analysis indicated that for every $10 \%$ increase in the price of fish, the willingness to pay increases by $0.31 \%$ from the mean level ceteris paribus. The willingness to pay function analysis results portray that against the classical demand theory, the demand for fish exists even though with increasing prices as indicated for Kochi, Kozhikode and pooled consumers. The willingness to pay function also establishes the surge in demand for fish consumption amidst high prices.

The fish food consumption pattern trends across the different study locales clearly portrayed that there exists significant demand for high value fish and fish products. The study spells out that the average household fish demand registered $9.34 \mathrm{~kg}$ shared across low value (6.49 kg) and high value fishes $(2.85 \mathrm{~kg})$. The mean expenditure on fish and fish products was estimated to be ₹982.81. The constraint analysis limiting fish consumption revealed that non-availability of preferred fishes, lack of quality fresh fish, extensive variations in price, high price, access to the source of purchase and consumption limited to seasonality were the main limits to consumption.

The most profound finding of the study was that $77.97 \%$ of the consumers were unaware about the low export prices of high value fishes. Again 54.61\% consumers felt the unavailability of high value fishes for consumption and $35.49 \%$ of the consumers were willing to eat high value fishes frequently if available. The willingness to pay function using Logit function indicated the existence of demand for high value fish consumption even at higher prices. The study poses caution that the non-availability of fish in the domestic fish market would pave way for a precarious situation wherein the domestic consumers will be devoid of high value fish in the market at affordable prices. Considering the fact that the export prices are lower than the domestic prices, increased export economies of scale reaped through quantity effect and not by price effect, would question the domestic fish food security. The study advocates the need for appropriate governmental regulations to ensure timely availability, easy accessibility and high affordability of high value fishes in the domestic market.

\section{References}

CMFRI 2019. Annual report 2018-19. ICAR-Central Marine Fisheries Research Institute, Kochi, Kerala, India, 320 pp.

DFID 2003. Project R7799: Changing food utilisation and its impact on poverty in Kerala, In: Major trends in the utilisation of fish in India: Poverty considerations. Department for International Development (DFID), UK, p. 1-4.

Garrette, H. E. and Woodworth, R. S. 1969. Statistics in psychology and education.Vakils, Feffer and Simons Pvt. Ltd., Mumbai, India, 329 pp.

Gogoi, B., Kachari, A., Dutta, R., Darshan, A. and Narayan, D. D. 2015. Fishery based livelihood approaches and management of fishery resources in Assam, India. Int. J. Fish. Aquatic Stud., 2(4): 327-330.

GoK 2019. Economic Review 2019. State Planning Board, Govt. of Kerala, Thiruvananthapuram, Kerala, India.

Gulati, L. 1984. Fisherwomen on the Kerala Coast: Demographic and socio-economic impact of a fisheries development project, Issue 8 of Women, work, and development, International Labour Organisation, United Nations Fund for Population Activities, ISSN 0253-2042.

Greene William, H. and David A. Hensher 2013. Revealing additional dimensions of preference heterogeneity in a latent class mixed multinomial logit model, Appl Econ., 45:14, 1897-1902, DOI: 10.1080/00036846.2011.650325.

Lusk, J. L. and Hudson, D. 2004. Willingness-to-pay estimates and their relevance to agribusiness decision making. Rev Agric. Econ., 26(2): 152-169.

Maynard, L. J. and Franklin, S. T. 2003. Functional foods as a value-added strategy: the commercial potential of "cancerfighting” dairy products. Rev. Agric. Econ., 25: 316-331.

Rajasenan, D. and Rajeev, B. 2012. Fishery commodity chain trap vis-à-vis global quality standards: An analysis of the Kerala marine fishery. Developing Country Studies, 2(5): 78-86. doi=10.1.1.462.3093\&rep=rep1\&type=pdf. 
Shyam, S. S., Geetha, R., Aswathy, N. and Vipin Kumar, V. P. 2012. Tradeoffs in Indian seafood trade - Forex earnings vis-a-vis domestic availability and affordability. In: Ann L. Shriver (Ed.), Visible possibilities: The economics of sustainable fisheries, aquaculture and seafood trade. Proceedings of the Sixteenth Biennial Conference of the International Institute of Fisheries Economics and Trade, 16-20 July 2012. Dar es Salaam, Tanzania. International Institute of Fisheries Economics and Trade (IIFET), Corvallis, USA.

Shyam, S. S. and Narayanakumar, R. 2012. World trade agreement and Indian fisheries paradigms: A policy outlook. Course manual, ICAR-Central Marine Fisheries Research Institute, Kochi, India, 457 pp.

Shyam, S. S. 2013. Demand and supply paradigms for fish food security in India. Seafood Export J., 43(5):34-40.
Shyam, S. S. 2013. Demand pattern and willingness to pay for high value fishes in India. J. Mar. Biol. Ass. India, 55(2): 48-54.

Shyam, S. S., Vipinkumar, V. P., Pushkaran, K. N., Suresh, V. K. and Harshan, N. K. 2013. Short stint night fish markets in Kerala: A case study. Mar. Fish. Inf. Ser. T\&E Ser., (216): 33-35.

Shyam, S. S., Safeena, P. K., Reeja Fernandez, Athira, P. R., Sunil, P. V., Harshan, N. K., Rahman M. Ramees, Athira, N. R. and Remya, R. 2017. Rapid assessment of the fish trade, arrivals and price realization in Kerala. Mar. Fish. Inf. Ser. T\&E Ser., (232): 24-27.

The Business Line 2017. Kerala to be a net deficit in fish availability. Kochi Bureau, 02 May 2017

Yadava, Y. S. and Mukherjee, R. 2007. Marine fisheries: Signs of growth visible, The Hindu Survey of Indian Agriculture, The Hindu Publication, p. 98-100. 